\title{
The Anglo-German Alliance Talks and the Failure of Amateur Diplomacy
}

Adam Lajeunesse, University of Calgary

In 1914 Great Britain and the German Empire were implacable enemies, embroiled in the greatest war the world had ever known.

84 However, little more than a decade previously relations between these two great powers were far different. From 1898-1903 the two states were engaged in extensive negotiations meant to cement their friendship with an Anglo-German alliance. The ultimate failure of these talks was largely the result of amateur diplomacy. It was the failure of men like Joseph Chamberlain and Hermann von Eckardstein who, through their impetuous and occasionally dishonest dealings, prevented the honest and constructive discourse which could have led the negotiations to a successful conclusion.

For nearly a century, historians have studied the failure of the AngloGerman alliance talks which took place from 1898 to 1903 . The importance of these discussions can hardly be underestimated as their ultimate failure ended what was perhaps the last great opportunity to reverse the tide of Anglo-German hostility; a hostility which eventually allowed the First World War to take on its global character. Over the previous century historians have analyzed the military and political positions of the two governments, the influence of popular opinion, and the personal dispositions of every principal 
actor towards the possibility of an agreement. While the dispute over the feasibility of a potential alliance has seemingly been approached from every conceivable angle, there remains today one area which has received scant attention, the nature of the talks themselves. Historians have written a great deal on the matters actually discussed by the British and German diplomats but have given less than adequate attention to the manner in which these matters were discussed. Without underestimating the obvious importance of the substance of the Anglo-German discussions, this paper will demonstrate the importance of the fashion in which the two states communicated their interests. The utter failure of Joseph Chamberlain and Hermann von Eckardstein, the two men responsible for initiating the talks, to bring their respective governments together owed as much to their amateurish diplomacy as to any other factor. The manner in which Britain and Germany conducted their negotiations failed to communicate either nation's position properly. Misinterpretation, suspicion, and confusion thus characterized these talks, prevented any productive discourse and ultimately doomed the talks to failure.

It was only with the publication of Baron Hermann von Eckardstein's memoirs and the German diplomatic documents in the mid 1920s that historians realized the full extent of the alliance talks which had taken place between Britain and Germany between 1898 and 1903. For nearly forty years, the prevailing opinion in the academic community was that the blame for what was considered to be a 'missed opportunity,' lay at the feet of men like the German Foreign Secretary Count Bernhard von Bülow and Baron Friedrich 
von Holstein, First Councilor of the German Foreign Office. ${ }^{1}$ Only more recently has scholarship by men like Rich, Monger, and Grenville shifted the historiography towards the understanding that these talks were in fact doomed from the outset and could never be considered a missed opportunity.

Every historian, in making a claim either for or against the feasibility of an alliance, has pointed to tangible political or military factors to illustrate the correctness of his position. John Mander refers to the geopolitical advantages an alliance would have offered both states. Coupled by the lack of any serious foreign policy conflicts, he believed an alliance should have been possible. ${ }^{2}$ Conversely, men like Paul Kennedy, H.W Koch, and Edward Benson have cited factors such as German imperial ambition, a lack of support in the British Cabinet, and a lack of popular support in both nations in their respective attempts to demonstrate the absence of any possibility for a successful Anglo-German agreement. ${ }^{3}$ The one constant is that the focus of these works has been on tangible political and military factors, on the arguments for or against an alliance rather than on how these arguments were represented by the actions of diplomats. Yet, a great deal of blame for the failure of the alliance talks rests, not only with political or military stumbling blocks, but on the shoulders of the poor diplomacy which might have overcome them.

The first diplomatic overture, which began the alliance negotiations came from Joseph Chamberlain, the Conservative

\footnotetext{
${ }^{1}$ Paul M. Kennedy, "German World Policy and the Alliance Negotiations with England 1879-1900," The Journal of Modern History vol. 45, no. 3 (December 1973): 605.

2 John Mander, Our German Cousins; Anglo-German Relations in the $19^{\text {th }}$ and $20^{\text {th }}$ Centuries (London: J. Murray, 1974).

${ }^{3}$ E.F. Benson, The Kaiser and English Relations, (London; New York; Toronto: Longmans, Green and Co.,1936) Koch; Kennedy. 
government's prominent Colonial Secretary. The Colonial Minister was unlike many of his aristocratic peers. Chamberlain had entered parliament on the strength of his tremendous wealth, since being well moneyed often served the same purpose as being well born. Chamberlain also lacked many of the stereotypical Victorian virtues such as patience and discretion. Yet, whatever Chamberlain lacked in these he made up in energy and determination. These qualities served him well in business but did not recommend a man for diplomatic work. Yet, in 1898 the Colonial Minster threw himself onto the international stage.

On 29 March, Chamberlain met with the German Ambassador, Count Paul von Hatzfeldt, who had come to discuss colonial grievances. To the "astounded" ambassador, Chamberlain offered a general defensive alliance. ${ }^{4}$ It was Chamberlain's desire to protect British colonial interests which prompted him to move towards an agreement with Germany. During the latter half of the nineteenth century, Britain's imperial position had been steadily eroding relative to the other European Powers. The expanding French colonial empire rubbed against British colonies in a number of places across the globe and created a great deal of friction in West Africa, Morocco, Siam, and most importantly Egypt. In India the threat of a Russian invasion was a persistent problem and the number of troops required to defend the colony increased every year. These challenges to British colonial power worried Chamberlain excessively and the Russian capture and subsequent lease of Port Arthur in Northern China in 1898 settled him on the need for a radical solution.

\footnotetext{
${ }^{4}$ H.W. Koch, "The Anglo German Alliance Negotiations: Missed Opportunity or Myth," History vol. 54, no 182 (1969): 381.

Past Imperfect

13 (2007) | @ | ISSN 1192-1315
} 
Chamberlain's attempt at diplomacy failed nearly as soon as it began. It failed because diplomatic converse is governed by a different set of rules from regular social or business interaction. A professional diplomat knows that messages are conveyed by more than what is openly declared. The timing of a message and the manner in which it is related are of paramount importance and every action no matter how small is seen to convey meaning and intent. It is said that during the Congress of Vienna, when the Austrian Count Metternich was told of the Russian ambassador's death, he is supposed to have declared: "now, I wonder what he meant by that.", Professional diplomats are trained to function in this environment, Joseph Chamberlain was not and for this reason he was unable to communicate properly with the German diplomats of the 'old school. ${ }^{6}$

The Colonial Secretary approached von Hatzfeldt not as a diplomat but as a businessman with a proposition. Chamberlain simply blindsided the ambassador; Count von Hatzfeldt, who had expected to talk about small colonial matters, was suddenly being offered an alliance by a British Minister. ${ }^{7}$ According to von Hatzfeldt's telegram to Berlin, Chamberlain laid out his case as a business proposition: Germany and Britain had no serious disputes or colonial conflicts and shared common enemies. The goal of an alliance would be to halt Russian and French encroachment in China.

\footnotetext{
${ }^{5}$ Ben Birnbaum, Prologue to Boston College Magazine, (Winter, 2003) [online] available at: http://www.bc.edu/publications/bcm/winter_2003/prologue.html. (17 July 2007).

${ }^{6}$ Hermann von Eckardstein, Ten Years at the Court of St. James', tr. George Young, (London: Thornton Butterworth Ltd., 1921), 103.

${ }^{7}$ The fact that Chamberlain was the Colonial Minister and was acting outside his sphere of authority and behind the back of the Prime Minister Lord Salisbury was particularly disconcerting to the Germans.
} 
In exchange for German assistance, Britain would be willing to support German colonial aims in that region. ${ }^{8}$

Chamberlain, who "detested the procedures and poses of the old traditional diplomacy with its finessing and bluffing," was wrong to believe that the German government would respond well to his open and forthright overture. ${ }^{9}$ The manner in which this proposal was conveyed shocked and worried the more cynical and suspicious men at the Willhelmstrasse. The Foreign Minister Count von Bülow and the First Councilor of the German Foreign Office, von Holstein were the two figures primarily responsible for German foreign policy and they expected deceit and maneuver from foreign diplomats. Such unconventional directness confused them. ${ }^{10}$ Chamberlain's request for haste on the German side and his desire for a prompt reply from Count von Hatzfeldt only served to deepen the suspicion of von Bülow and von Holstein that the British Minister was somehow attempting to trap Germany. ${ }^{11}$

To Count von Bülow this offer was but the latest English attempt at "exploiting her friends ... i.e. the tactics of pushing others to the front whilst herself remaining behind." 12 The assumption in Berlin was that Britain, knowing it was going to be drawn into a war with Russia over China very soon, was trying to tie Germany to its cause as quickly as possible. Von Holstein concurred: "they are only

${ }^{8}$ E.T.S. Dugdale ed., German Diplomatic Documents $1871-1914$ vol. III: The Growing Antagonism, 1898-1910, (New York: Methuen and Co., 1930), II, no. 196: 29 March, 1898.

9 von Eckardstein, Ten Years at the Court of St. James', 103

${ }^{10}$ Edgar Johnson and John D. Bickford, "The Contemplated Anglo-German Alliance: 1890-1901," Political Science Quarterly vol. 42, no. 1 (March, 1927): 26.

${ }^{11}$ Dugdale, German Diplomatic Documents , vol. II, no. 196: 29 March, 1898.

${ }^{12}$ Friedrich von Holstein, The Holstein Papers vol. IV, ed. Norman Rich (London: Cambridge University Press, 1955), no. 646 Hatzfeldt to Bulow: 28 March, 1898, 66. 
thinking of how they can send the Triple Alliance into fight and stay out themselves."13

Chamberlain's understanding of Wilhelmine Germany was flawed. Chamberlain, thinking as a businessman, recognized the financial opportunities available to both nations in China and assumed that Germany did also. It seems highly unlikely that he was 90 actually planning to embroil Germany in a conflict with Russia. Count von Hatzfeldt even went as far as to write von Bülow to reassure him that Chamberlain's aim had not been nefarious but was intended only to force Russia to "eat humble pie in the face of an alliance between England and the Triple Alliance." 14 However, Germany had no intention of halting the Russian expansion eastwards, since it diverted the Russian Army's attention away from East Prussia. Despite the increasing German concern for colonies, its primary concern was always for frontier security. On the margins of von Hatzfeldt's report on Chamberlain's overture, the Kaiser wrote "[stop Russia] certainly not! The deeper the Russians get involved in Asia, the quieter they will be in Europe." 15

Von Holstein, von Hatzfeldt, and Kaiser Wilhelm II all misunderstood Chamberlain's rather undiplomatic advance, reading into it far more than was actually there. While the German government saw the request as a British trap, it was also interpreted as a sign of weakness. The haste with which it was made and the speed Chamberlain had encouraged in their reply told the Willhelmstrasse that Britain was in immediate danger. "It was an

\footnotetext{
${ }^{13}$ von Holstein, The Holstein Papers IV, no. 651, von Holstein to von Hatzfeldt: 30 April, 1898, 75.

${ }^{14}$ von Holstein, The Holstein Papers IV, no. 649, von Hatzfeldt to von Bülow: 20 April 1898, 72

${ }^{15}$ Norman Rich, Friedrich von Holstein: Politics and Diplomacy in the Era of Bismarck and Wilhelm II vol. 2 (London: Cambridge University Presses, 1965), 578. 
article of faith in Berlin that England would one day urgently require Germany's support" and it seemed to Berlin that that day had arrived. ${ }^{16}$ Germany recognized Britain's precarious position in the Far East and to see a British minister asking for help delighted the Kaiser who proclaimed "the Jubilee swindle is already over!"17

Chamberlain's overtures to Germany had won only one supporter, Baron Hermann von Eckardstein, First Secretary of the German Embassy in London. Chamberlain's German counterpart, von Eckardstein managed to surpass even the Colonial Secretary in his own maladroit attempts at diplomacy. Like Chamberlain, von Eckardstein was not a professional diplomat and lacked the training and experience necessary to conduct important negotiations. He was a German nobleman who had married an English heiress. An anglophile, von Eckardstein circulated in both German and British social circles and had a great desire to play a larger part in international politics. ${ }^{18}$

Von Eckardstein's character is best represented by the story of his introduction to the Bismarcks. He first attracted the attention of Count Herbert von Bismarck during his posting in the United States during the 1890's. At dinner in a Washington restaurant with a group including the former Chancellor's son, von Eckardstein bet his fellow diners that he could reach the street faster than any of them. They leapt from their chairs and bolted down the stairs while von Eckardstein calmly jumped out an open window. He sprained his ankle but won the bet. It was exactly the kind of flamboyant gesture

\footnotetext{
${ }^{16}$ von Holstein, cited in G.P. Gooch, Before the War: Studies in Diplomacy vol. I, (London; New York; Toronto: Longmans, Green, 1936), 7.

${ }^{17}$ J.L. Garvin, The Life of Joseph Chamberlain vol. III (London: McMillan, 1934), 269.

${ }^{18}$ Robert K. Massey, Dreadnought: Britain Germany and the Coming of the Great War (New York: Random House, 1991), 243.
} 
to impress a Bismarck and he found himself with a posting to the German Embassy in London in 1898. ${ }^{19}$

Like Chamberlain, von Eckardstein lacked the tact, discretion, subtlety, and above all the patience to conduct diplomacy effectively. Von Eckardstein desired an alliance between his homeland and the land he had come to love and he was also totally unwilling to wait for such an agreement to come from the Willhelmstrasse or, as he termed it, "the Great Fool's Paradise." 20 Von Eckardstein was also hopeful that if he were instrumental in the successful conclusion of an alliance with Britain, the post of Ambassador in London would fall to him after the ailing Count von Hatzfeldt's retirement. ${ }^{21}$ Von Eckardstein thus approached the alliance negotiations in the same spirit as did Chamberlain, with undue haste and little regard for the formal niceties of high diplomacy.

In early April shortly after von Hatzfeldt, on instructions from von Bülow, had decided to drop the subject of an alliance, von Eckardstein took it upon himself to see it revived. Von Eckardstein was spurred on in this manner by the Kaiser, whose own diplomatic tact was also often severely lacking. On 9 April, the German Emperor had invited von Eckardstein to dinner with him at Homburg where he had talked for over an hour, speaking favourably of an alliance and encouraging von Eckardstein's "airy dreams."22 The Kaiser, while unwilling to "pull English chestnuts out of the fire" at

\footnotetext{
${ }^{19}$ Rich, Friedrich von Holstein, 575.

${ }^{20}$ von Eckardstein, Ten Years at the Court of St. James', 213.

${ }^{21}$ von Eckardstein's designs on the Ambassador's position were well concealed and were not suspected until May 1901 when von Hatzfeldt wrote a letter to von Holstein warning him of von Eckardstein machinations: von Holstein, The Holstein Papers IV, no. 774, von Hatzfeldt to von Holstein: 26 May 1901, 22527.

22 Rich, Friedrich von Holstein, 574.

Past Imperfect 13 (2007) | @ | ISSN 1192-1315
} 
the moment, was hopeful of bringing Britain into an alliance at a more opportune moment later on. ${ }^{23}$ To the Kaiser it was imperative "to keep official sentiment in England favourable to [Germany] and hopeful" both to ensure the possibility of a later agreement as well as to win as many colonial concessions as possible from a Britain presumably desperate for German friendship. ${ }^{24}$ To keep the British optimistic, the Kaiser foolishly used von Eckardstein as a "decoy." 25

On his return from Berlin to London von Eckardstein rushed to meet Chamberlain, reporting that: "[The Kaiser] said to me at Homburg that an alliance with England would be the best thing in the world. It would secure the peace for fifty years. ${ }^{26}$ The deception is revealed by a letter which the Kaiser wrote to the German Foreign Office the next day outlining his true desire to put off any British alliance to a time when it could be concluded on terms more advantageous to Germany. ${ }^{27}$ To deliberately deceive von Eckardstein in the hopes of deceiving the British was diplomacy at its most dishonest, though not entirely out of character for the Kaiser. However, by the time the message had reached Chamberlain on the morning of the 22 April, it had been further distorted by von Eckardstein, a problem which was to become a common occurrence. According to Norman Rich, "there can be no doubt that the Kaiser's offer as represented to Chamberlain was largely if not entirely the invention of Eckardstein." 28 However, given the indiscreet

\footnotetext{
${ }^{23}$ Gooch, Before the War, 205.

${ }^{24}$ Massey, Dreadnought: Britain Germany and the Coming of the Great War, 245.

${ }^{25}$ Ibid.

${ }^{26}$ Chamberlain's Fifth Memorandum, Colonial Office, April 261898 in Garvin, The Life of Joseph Chamberlain, 276.

${ }^{27}$ Kaiser to Willhelmstrasse April 10, 1898 in Garvin, The Life of Joseph

Chamberlain, 270.

${ }^{28}$ Rich, Friedrich von Holstein, 576-77
} 
tendencies of the Kaiser it seems highly likely that he did mention something in favour of an alliance for von Eckardstein to embellish.

Chamberlain, unaware at the level of dishonesty he was being faced with, was happy to receive von Eckardstein's news. Later that day, the 22 April, von Eckardstein invited Chamberlain to dine with himself and Ambassador von Hatzfeldt on the $25^{\text {th }}$ to 94 discuss the matter further. Chamberlain eagerly accepted. However, von Eckardstein had a problem, as he did not have the authority to begin talks. His solution was to inform Count von Hatzfeldt that Chamberlain had been the one to ask for the audience, implying that Chamberlain was once again initiating the discussions. Count von Hatzfeldt sent a telegram to Berlin that day informing them that Chamberlain had renewed his efforts. ${ }^{29}$ Both governments had thus fallen under the impression that the other had initiated the talks and was anxious to make generous proposals!

During their meeting, Count von Hatzfeldt was perplexed by Chamberlain's reserve as he had expected the Colonial Minister to renew his efforts towards an alliance. Chamberlain was equally perplexed when the grand proposals hinted at by von Eckardstein did not materialize and all he heard from von Hatzfeldt were demands for British colonial compensation. Von Hatzfeldt's report to Berlin contained a demonstration of how frustrated Chamberlain had become: "Mr. Chamberlain ... [said] that if his idea of a natural alliance with Germany must be renounced, it would be no impossibility for England to arrive at an understanding with Russia or France. ${ }^{30}$ Von Eckardstein's amateur diplomacy had backfired with grave consequences. Rather than bringing Chamberlain and von Hatzfeldt to agreement, his deception merely separated the two

\footnotetext{
${ }^{29}$ Ibid., 577.

${ }^{30}$ Massey, Dreadnought: Britain Germany and the Coming of the Great War, 246.

Past Imperfect

13 (2007) | @ | ISSN 1192-1315
} 
parties further. When the façade created by von Eckardstein's lies caved in, it left both Chamberlain and von Hatzfeldt disappointed and suspicious, even to the point of evoking a threat from Chamberlain to seek an alliance with Germany's enemies.

One week after Chamberlain's disastrous meeting with von Hatzfeldt, on 2 May, the Prime Minister, who had returned from a cure in France, had a chance to meet with the German Ambassador. Lord Salisbury had always had a low opinion of von Eckardstein, once referring to him derisively as "that fat fellow who married Maple's daughter;" yet he had been informed by Chamberlain of the great offers von Eckardstein had brought back with him from Homburg and the Prime Minister was interested in hearing them. ${ }^{31}$

While in France, Salisbury had been kept informed of the progress of Chamberlain's "amateur negotiation[s]" by his nephew, the leader of the House of Commons, Arthur Balfour. ${ }^{32}$ In early April after meeting with von Hatzfeldt and before von Eckardstein's intervention, Balfour wrote that the Germans seemed only inclined to offer an agreement on unfavorable terms. ${ }^{33}$ However, the Prime Minister was presented with a different picture upon his return to London in late April. In a letter to Salisbury on the $29^{\text {th }}$, Chamberlain told the Prime Minister of his conversations with von Eckardstein and how "in every case the interviews were sought by the Germans and the initiative was taken by them." Von Eckardstein's decision to go to Chamberlain without direct authorization from his government thus had the same result as Chamberlain's advance. The British now

\footnotetext{
${ }^{31}$ Ibid., 257.

${ }^{32}$ Balfour to Salisbury: 14 April, 1898, in J.A.S. Grenville, Lord Salisbury and Foreign Policy the Close of the Nineteenth Century, (London: The Athalone Press, 1964), 158.

${ }^{33}$ Balfour to Salisbury: 14 April, 1898, in Grenville, Lord Salisbury and Foreign Policy the Close of the Nineteenth Century, 158.
} 
believed that by initiating the conversations, the Germans were now prepared to lower their demands in order to achieve an understanding. Salisbury met von Hatzfeldt on 2 May with a fundamentally flawed understanding of the situation. The German government had never authorized any talks and was in no mood to compromise with the British whom, after Chamberlain's overtures, they felt to be the weaker party.

Salisbury met von Hatzfeldt expecting substantial proposals like Chamberlain had before him. Knowing nothing of von Eckardstein's exaggerations, the ambassador made only "general reflections on the advantages of a better understanding." ${ }^{34}$ Next to what Salisbury had expected, this talk seemed very cool indeed. He later wrote to Chamberlain that von Hatzfeldt's "business was evidently to throw cold water." ${ }^{35}$ Unknowingly von Hatzfeldt had conveyed to the British Prime Minister that his government had offered and then withdrawn an alliance. In a mood of suspicion and resentment, talk of an alliance was largely suspended for two years and not taken up again in earnest until 1901.

By 1901, public opinion in Britain was more favourable to Germany than it had been in years, thanks largely to the Kaiser's devoted behavior at Queen Victoria's funeral in January. ${ }^{36}$ In an environment of improved relations, von Eckardstein felt that the Willhelmstrasse was not taking an active enough role in bring Britain into an alliance and so he took the mission upon himself and again renewed his amateur attempts at diplomacy. With Count von Hatzfeldt chronically ill and unable to perform his duties, increasing responsibility fell upon von Eckardstein who, like Chamberlain in

\footnotetext{
${ }^{34}$ Salisbury to Chamberlain: 2 May, 1898 in Garvin, The Life of Joseph Chamberlain 279.

${ }^{35}$ Ibid.

${ }^{36}$ Massey, Dreadnought: Britain Germany and the Coming of the Great War, 301

Past Imperfect

13 (2007) | @ | ISSN 1192-1315
} 
1898, began to operate above his position. Von Holstein, not wishing to replace his friend von Hatzfeldt, allowed von Eckardstein to continue to carry out the business of the German Embassy in von Hatzfeldt's name. Von Holstein never suspected von Eckardstein's deeper political ambitions or that may he be misrepresenting German interests to the British. To work against the wishes of Ambassador von Hatzfeldt would have been illogical since it was only because of von Hatzfeldt that von Eckardstein exercised any influence over the German Embassy. ${ }^{37}$ In the words of Norman Rich, "such behavior would have been so irresponsible, and from a political and personal point of view so senseless and self-defeating, that it was beyond even the most mistrustful imagination." 38 However this seems to have been the case.

On 18 March in a conversation with Lord Lansdowne, von Eckardstein again proposed a general alliance. Lansdowne had taken over the position of Foreign Secretary from the ageing Prime Minister Salisbury on 12 November, 1900 and was now responsible for any alliance talks. With Lansdowne at the Foreign Office there would never be a better opportunity to secure an agreement. The new Foreign Secretary was more open to the idea of an alliance than Lord Salisbury, whose influence seemed to be steadily waning.

The alliance proposed by von Eckardstein was a defensive agreement directed against Russia and France which would come into effect only if one of the contracting parties was attacked by two hostile states. This was exactly the sort of overture which von Eckardstein had been expressly forbidden to make. In a letter received 9 March 1901, von Holstein wrote to him: “you must on no

\footnotetext{
${ }^{37}$ von Holstein, The Holstein Papers IV, no. 775, von Holstein to von Hatzfeldt: 27 May, 1901, 227-28.

${ }^{38}$ Rich, Friedrich von Holstein, 629.

Past Imperfect 13 (2007) | @ | ISSN 1192-1315
} 
account raise this idea. It must come from them." ${ }^{39}$ Von Holstein knew that the party which initiated discussions would be considered the one most desperate for an agreement and thus expected to give up the most. However, like Chamberlain in March 1898, von Eckardstein had little use for diplomatic subtlety. Von Eckardstein let it be known that his overture had not been made under 98 instructions from his government. ${ }^{40}$ However, as the Germans did not believe Chamberlain in 1898, the British could not believe that such an offer would be made entirely without government sanction. In a letter to Lord Lansdowne the British Ambassador to Germany, Sir. Frank Lascelles, illustrated British thinking by writing: "I cannot believe that von Eckardstein would have suggested an alliance without authority."

In a continuation of his 1898 tactics, von Eckardstein attempted to deceive both governments in order to keep both interested. From Lansdowne's report of 18 March it is obvious that von Eckardstein had initiated these discussions. However, in von Eckardstein's report he gives the initiative to the British Foreign Minister. ${ }^{42}$ In his Lebenserinnerungen, von Eckardstein goes so far as to admit to concealing the fact that he had encouraged Lansdowne towards an alliance: "If there were a defensive alliance covering all eventualities, Germany would of course be in a position to localize a war between Russia and Japan by localizing France." ${ }^{43}$ This passage

\footnotetext{
${ }^{39}$ von Eckardstein, Ten Years at the Court of St. James', 203

${ }^{40}$ Gooch, G.P., D and H. Temperley eds., British Documents on the Origins of the War 1898-1914 vol. I, (London: Johnson Reprint Company Ltd., 1927), II, no. 77, 61.

${ }^{41}$ Gooch and Temperley eds., British Documents on the Origins of the War, II, 61 no. 78 .

${ }^{42}$ Gooch and Temperley eds., British Documents on the Origins of the War, II, 60, Editorial Note.

${ }^{43}$ Ibid.
} 
was excluded from his report to von Holstein lest "that eccentric" should denounce him for overstepping his bounds. ${ }^{44}$

Four days after von Eckardstein's proposal to Lansdowne, the British Foreign Secretary had a meeting with the ill Count von Hatzfeldt. During this conversation he submitted a memorandum to the ambassador asking for clarification on a number of points concerning a possible alliance. Von Hatzfeldt was surprised to receive such a request but provided him with the answers. ${ }^{45}$ Von Hatzfeldt's letter to Count von Bülow clearly reveals that the Germans believed it had been Lansdowne who had initiated the talks, when in fact Lansdowne was merely seeking clarification on something which Germany's de facto ambassador had told him four days past. ${ }^{46}$ By April, both the German and the British government had been duped into believing that the other had restarted the negotiations.

On 9 April von Eckardstein returned to the subject with Lansdowne. ${ }^{47}$ By this point, Lansdowne was beginning to suspect the legitimacy of von Eckardstein's claims. He knew that von Eckardstein was speaking unofficially, however he needed to know if von Eckardstein had any support from the Kaiser and the German government. To this question von Eckardstein "hummed and ha'd" and finally said that what had been done had been done "with the knowledge of persons very near the Emperor, and who knew the means of judging [his] ideas. ${ }^{, 48}$ He mentioned von Holstein as one of

${ }^{44}$ Ibid.

${ }^{45}$ Dugdale, German Diplomatic Documents, IX, XVII, no. 46.

${ }^{46}$ Gooch and Temperley, eds., British Documents on the Origins of the War II, 61, no. 78.

${ }^{47}$ Gooch and Temperley eds., British Documents on the Origins of the War II, 62

no. 80.

${ }^{48}$ Ibid., 63 no. 81 . 
these people. ${ }^{49}$ To Lascelles, Lansdowne wrote that "[i]t is not always easy to determine how much of Eckardstein's communications are de son proper cru. ${ }^{, 50}$

On 15 May von Hatzfeldt reported to Berlin that Lansdowne had again raised the alliance question and that Lord Salisbury, long thought to be the principal stumbling block in the British government, had agreed in principal to an alliance and desired that the terms for such an agreement be placed into writing in draft form. $^{51}$ It is true that Salisbury had offered his conditional acceptance, yet the notion of a draft treaty did not originate with the British Prime Minister. It seems that von Eckardstein had taken the initiative and offered this written proposal to Lansdowne. That von Hatzfeldt felt that Lansdowne's talk of a written memorandum was a British initiative indicates that von Eckardstein had never told his superiors that it was he who had made the offer. "This meant that the German government negotiated on the basis of offers that were almost certainly never made," virtually dooming any attempt at productive communication. ${ }^{53}$

By the end of May 1901, von Eckardstein's diplomatic bungling had thoroughly distorted the views of both the German and British governments. His "hopelessly amateurish concept of the diplomatic process" created the strong impression in both capitals that the other side had initiated the talks and had made the first verbal and written offers. Both governments took this to mean that the other side was more in need of an agreement than either of them

\footnotetext{
${ }^{49}$ There is no record of von Holstein's knowledge of von Eckardstein's maneuvers.

${ }^{50}$ Gooch and Temperley eds., British Documents on the Origins of the War II, 63 no. 81; The Germans had this problem dealing with Chamberlain as well.

${ }^{51}$ Dugdale, German Diplomatic Documents, IX, XVII. no. 58: May, 171901.

${ }^{52}$ Gooch and Temperley eds., British Documents on the Origins of the War, II, 66 no. 84: May, 241901.

${ }^{53}$ Rich, Friedrich von Holstein, 628.

Past Imperfect 13 (2007) | @ | ISSN 1192-1315
} 
really were. The Germans, having been misled at least since January 1901, were confident that the British were 'in the bag' and felt that the price for an alliance could safely be raised. The British felt that there was little reason to accept a high German price since it had been the Germans who had requested an alliance to begin with. The situation was well summed up by a Caran d'Achè cartoon published early in 1901. In it the Kaiser, strutting onboard his yacht, the Hohenzollern, says “J'ai foutu l'Angleterre dans ma poche." King Edward, next to the Kaiser smoking a cigar replies 'L'Allemagne est dans le sac." ${ }^{54}$ By this point "only von Eckardstein knew the real state of affairs, and even he must have been confused at this time."

The German response to what they perceived to be Britain's request for an alliance was naturally to offer one on terms most favorable to themselves. ${ }^{56}$ By the middle of April, Berlin had already decided that if Britain needed its help it should have to go through Austria. In doing this, Germany hoped to allay Austrian fears which had recently arisen that Germany would attempt to partition the Hapsburg Empire after the death of Emperor Franz Joseph. ${ }^{57}$

The German government believed that the British were willing to sign onto the Triple Alliance was based on the many misleading reports from von Eckardstein, who had given the Willhelmstrasse the impression that Lansdowne was "fully determined" to carry an alliance through. Salisbury, portrayed as being controlled by Lansdowne, was declared to be in favour of an agreement: "Lord Salisbury, in spite of his old inclination to make trouble, is now willing to accede to the policy of Lansdowne and

${ }^{54}$ von Eckardstein, Ten Years at the Court of St. James', 196

${ }^{55}$ Rich, Friedrich von Holstein, 650.

${ }^{56}$ According to von Eckardstein's memoirs, By 25 March the Germans thought

success to be practically assured.

${ }^{57}$ Dugdale, German Diplomatic Documents IX, XVII, no. 53: April 141901. 
Chamberlain and to agree to a defensive alliance." 58 The reality was that ever since March, Lansdowne, while receptive to von Eckardstein's ideas, had always been cautious. Concerned about surrendering foreign policy control to Berlin and entangling Britain in a continental war, Lansdowne had never been as enthusiastic as von Eckardstein made him out to be. By April 1901 Salisbury had 102 agreed in principal to negotiating an alliance. However he was not the puppet which von Eckardstein made him out to be. Von Eckardstein had also misled Berlin into thinking that the Prime Minister was now a firm supporter of an alliance. Only six days after von Eckardstein wrote von Holstein to ensure him of Salisbury's desire for an alliance, the Prime Minister wrote in his Memorandum of 29 May:

... I think it is open to much question whether the bargain would be for our advantage. The liability of having to defend the German and Austrian frontiers against Russia is heavier than that of having to defend the British Isles against France. Even, therefore, in its most naked aspect the bargain would be a bad one for this country. Count Hatzfeldt speaks of out "isolation" as constituting a serious danger for us. Have we ever felt that danger practically ... It would hardly be wise to incur novel and most onerous obligations, in order to guard against a danger in whose existence we have no historical reason for believing. [Italics the authors] ${ }^{59}$

One of the reasons the alliance talks had continued for so long was the fact that the British had been kept in the dark about Germany's real policy. By late march, Germany had already decided that British

\footnotetext{
${ }^{58}$ von Eckardstein, Ten Years at the Court of St. James', 220.

${ }^{59}$ Gooch and Temperley eds., British Documents on the Origins of the War II, 68, no. 86: May 291901. 
membership in the Triple Alliance would be more desirable than a bilateral treaty. ${ }^{60}$ Yet, von Eckardstein purposefully kept from Lansdowne von Holstein's desire to include the other members of the Triple Alliance. ${ }^{61}$ It was late May before von Eckardstein "incidentally" mentioned to the British that Austria and Italy would have to be included in any agreement. ${ }^{62}$ To Lansdowne this was a "most important point." ${ }^{63}$ For Britain to ally itself with Germany's partners would be to surrender a great deal of control over British foreign policy to the decaying Austrian Empire, which was considered the new 'sick man' of Europe, and to Italy which was not even considered by many to be a Great Power. ${ }^{64}$ In a meeting with Count von Hatzfeldt on 23 May, Lansdowne was officially told that if Britain wanted an agreement, it must now join the Triple Alliance.

The German belief that Britain was ready to join the Triple Alliance was based entirely on a misunderstanding of the British position built over the years through poor diplomacy. Dating back to 1898, the German government mistook Chamberlain's hasty proposals as an offer to join the Triple Alliance. ${ }^{65}$ Bolstered by numerous misleading reports from von Eckardstein, Berlin had good reason to believe that Britain had more at stake in the alliance talks than it actually did and was ready to make a commitment on German

${ }^{60}$ Dugdale, German Diplomatic Documents IX, XVII no. 350. Memorandum by von Holstein: March 27, 1901.

${ }^{61}$ von Eckardstein, Ten Years at the Court of St. James', 210.

${ }^{62}$ Gooch and Temperley eds., British Documents on the Origins of the War II, 64, no. 82: May 24, 1901.

${ }^{63}$ Ibid.

${ }^{64}$ Ibid.

${ }^{65}$ Dugdale, German Diplomatic Documents II, XIV, no. 196 - Chamberlain had in fact said this would be the "equivalent" of joining, a subtle difference. While Hatzfeldt did report the offer accurately, it was misinterpreted by Bülow and the Kaiser. 
terms. ${ }^{66}$ There was however, nobody in the British government in favor of joining into any kind of agreement with Austria and Italy.

In an effort to clarify the German position, Lansdowne requested the memorandum which von Eckardstein had promised him in a week before. ${ }^{67}$ The request reached the German embassy and was received by Count von Hatzfeldt who, having somewhat recuperated, had now resumed his duties. Von Hatzfeldt was naturally shocked by the request, since von Eckardstein had led him to believe that it was Lansdowne who had offered to provide one. In his reply to Lansdowne, he did his utmost to stall for time, pleading that von Eckardstein was not in London, and that he would return soon. ${ }^{68}$

Only with this revelation, that von Eckardstein had been negotiating far outside his limits, did von Hatzfeldt realize the character of his subordinate. In a letter to von Holstein on 26 May he informed the First Consul both of von Eckardstein's diplomatic blunder and his suspicion that the young man now wanted his job (both true) ${ }^{69}$ In his reply, von Holstein was unable to believe in such duplicity and, placing more faith in von Eckardstein than his long time friend and Germany's longest serving diplomat, asked von Hatzfeldt to politely refuse Lansdowne and to trust in von Eckardstein. ${ }^{70}$

Back in charge of the negotiations with the British, the still ailing von Hatzfeldt faced an insurmountable hurdle created by three

\footnotetext{
${ }^{66}$ von Holstein, The Holstein Papers IV no. 784, von Bülow to von Holstein: 5 August, 1901, 235-36.

${ }^{67}$ Gooch and Temperley eds., British Documents on the Origins of the War II, no. 84: May 24 1901, 66.

${ }^{68}$ Ibid., 70 Enclosure 2.

${ }^{69}$ von Holstein, The Holstein Papers IV, no. 774, von Hatzfeldt to von Holstein: 26 May, 1901, 225-27.

${ }^{70}$ von Holstein, The Holstein Papers IV, no. 775, von Holstein to von Hatzfeldt: 27 May, 1901, 227-28.
} 
years of miscommunication, hostility, and general diplomatic bungling. The German position had never reached British ears unadulterated through von Eckardstein and the British were confused as to what Germany's position on an alliance was. How little the British government understood the German position is demonstrated by a memorandum drawn up by Sir Thomas Sanderson, the UnderSecretary of State for Foreign Affairs, on 27 May: “. . . [I]t seems to me that [an alliance] will practically amount to a guarantee to Germany of the provinces conquered from France, and that is the way in which the French will look at it. I do not see exactly what Germany will guarantee to us." ${ }^{, 71}$ The Germans had entirely failed to communicate their proposals to the British. The Germans had intended that the British colonies be protected by the terms of the alliance; the British Empire would be counted as a single unity alongside the triple Alliance. The British government fundamentally misunderstood the German position, believing that the agreement would apply only to Great Britain itself. This, in addition to von Hatzfeldt's attempt to avoid sending Lansdowne the memorandum which had been promised him by von Eckardstein, bred further mistrust and frustration in the British Cabinet. ${ }^{72}$ In June von Hatzfeldt, now very ill, was replaced by Paul von Wolff-Metternich. By the time of his departure, Lansdowne had already begun to lose interest in dealing with the Germans and began avoiding the question of an alliance. ${ }^{73}$

\footnotetext{
${ }^{71}$ Gooch and Temperley eds., British Documents on the Origins of the War, II, 66, no. 85.

${ }^{72}$ Von Holstein feared that to offer the British this memorandum would imply that Germany was initiating the conversations. He wanted to be sure that Britain agreed in principal to an alliance before details were discussed.

${ }^{73}$ von Holstein, The Holstein Papers IV, no. 777, p. 230; Gooch, v. II, 71-72. 
The price of joining the triple alliance was simply too high. No Cabinet minister was prepared to surrender control over Britain's foreign policy to Italy and Austria nor commit themselves to fighting for Italian or Austrian interests. Britain also felt little need for either Italian or Austrian assistance in any part of the world and to align itself with either power would have meant a much greater danger of being drawn into regional or larger wars, without any benefit to Great Britain. In view of the fact that Germany was perceived as the party to have initiated the most recent talks, it seemed strange that they would set so obviously high a price for British assistance. In November 1901, Lansdowne let it be known that he would still consider German proposals in the future which did not involve Austria and Italy; however the notion of a Quadruple Alliance was a nonstarter. $^{74}$

By 19 December 1902 the British government had already moved to formally end alliance talks. On 8 February 1903, King Edward VII invited all foreign ambassadors to Marlborough House. Von Eckardstein, who attended representing Germany, saw the French Ambassador, Paul Cambon, and Chamberlain go off together into the billiards room. Straining to listen he picked up only the words 'Morocco' and 'Egypt.' Fifteen minutes later, the King spoke to von Eckardstein and told him that

. . . For a long time at least, there can be no more any question of Great Britain and Germany working together in any conceivable matter. We are being urged more strongly than ever by France to come to an agreement with her in all colonial disputes and it will probably be best in the end to make such a settlement. ${ }^{75}$

\footnotetext{
${ }^{74}$ Gooch and Temperley eds., British Documents on the Origins of the War II, no. 92,76

${ }^{75}$ von Eckardstein, Ten Years at the Court of St. James', 230. 
The Anglo-German alliance talks, which stretched from 1898 to the beginning of 1903 had the potential to bring Britain and Germany together in a way which would have drastically reordered the balance of power in Europe and potentially saved the continent from imploding in 1914. What ultimately doomed these talks to failure was the manner in which they were carried out. From the beginning, the negotiations were carried out by amateur diplomats. Men like Joseph Chamberlain and Hermann von Eckardstein had a poor understanding of how a diplomat was supposed to convey himself on the international scene. The brashness of Chamberlain and the dishonesty of von Eckardstein, both of whom had grossly exceeded their authority, left both the German and British Foreign Offices with a skewed understanding of the real position of the other. During the alliance talks both the British and the Germans utterly failed to accurately communicate their positions, concerns, and requirements vis-à-vis an alliance. The lack of proper communication between the two nations prevented any productive conversations and ensured that only suspicion, bitterness, and conflict would result. 